\title{
Sustainable medicines use in clinical practice - it is time to help the teacher
}

\author{
Michiel Bakkum ${ }^{1}$, Milan Richir², Michiel Agtmael ${ }^{3}$, and Jelle Tichelaar ${ }^{3}$ \\ ${ }^{1}$ Amsterdam UMC, Vrije Universiteit \\ ${ }^{2}$ Amsterdam UMC - Locatie VUMC \\ ${ }^{3} \mathrm{VU}$ University medical center
}

December 30, 2021

\section{Manuscript title:}

Sustainable medicines use in clinical practice - it is time to help the teacher

\section{Authors}

Bakkum, M.J'1,2. (0000-0003-0928-812X); Richir, M.C ${ }^{1,2}$; van Agtmael, M.A. ${ }^{1,2}((0000-0002-7966-6934)$ and Tichelaar $\mathrm{J}^{1,2}$. (0000-0002-7485-9219) on behalf of the EurOP ${ }^{2} \mathrm{E}$ consortium

Author's affiliations1. Amsterdam UMC, Vrije Universiteit Amsterdam, Department of Internal Medicine, Section Pharmacotherapy, De Boelelaan 1117, 1081 HV, Amsterdam, Netherlands

2. Research and Expertise Centre in Pharmacotherapy Education (RECIPE), De Boelelaan 1117, 1081 HV, Amsterdam, The Netherlands

Main text (word count $741 / 800$ )

We read the invited review on sustainable medicines use in clinical practice by Adeyeye et al[1] and would like to congratulate the authors with the captivating way in which they used scientific facts combined with very practical solutions to convey their call to action. This call is primarily addressed to the NHS, which the authors suspect will resonate with other health systems. While we fully agree with necessity of this top-down approach, we additionally believe that there is much to be gained by making future prescribers more knowledgeable and aware about the impact they have on planetary health. The article remains very brief about next generation of healthcare professionals by quoting the General Medical Council's statement that "newly qualified doctors must be able to apply the principles, methods and knowledge of population health and the improvement of health and sustainable healthcare to medical practice" [2]. However, the underlying question - how we effectively train future healthcare professionals in these attitudes underpinned by knowledge - is not addressed.

The Association for Medical Education in Europe's (AMEE) recent consensus statement provides a clear global, collaborative, representative and inclusive vision on how to educate an interprofessional workforce that can provide sustainable healthcare and promote planetary health[3]. One of the cornerstones in enacting this vision is via faculty engagement and development, and it is here that we foresee difficulties for sustainable clinical pharmacology and therapeutics (CPT) education. CPT teachers often have to balance their teaching tasks with clinical duties and in many countries there is a shortage of clinical pharmacologists. To incorporate sustainable prescribing in their teaching is something that most teachers simply do not have time for and even if they have the time, they may feel that there are more urgent improvements to be made. Many have stated intend to progress to more problem-based curricula, but recent surveys show that this transition is 
slow at best $[4,5]$. Moreover, the (mostly generation $\mathrm{X}$ or older) teachers may not be as invested in the issues of planetary health as the current (generation $\mathrm{Y}$ and $\mathrm{Z}$ ) young doctors and students and they may not feel confident that they have the expertise to teach about it[6].

If we want large numbers of students to learn about sustainable prescribing, it is of utmost importance to make the job of the teacher as easy as virtually possible. That means not expecting everyone to singlehandedly invent the wheel, but to collaboratively create standpoints, teaching materials and faculty development (or "teach the teacher") materials and to share them openly. That is free (without cost or copyright restrictions) and easy to re-use, revise (e.g. to local standards if necessary) and redistribute (e.g. local versions, improvements or translations). This is the goal of the European Open Platform for Prescribing Education (EurOP $\left.{ }^{2} \mathrm{E}\right)$. Aimed at improving and harmonizing international CPT education, EurOP ${ }^{2} \mathrm{E}$ is an online environment for CPT teachers to collaborate and to share and create open educational resources. The framework for the platform was recently published[7], and it is set to go live in early 2022. Alike the call to action towards the NHS, we hereby make an appeal for teachers in CPT to join the EurOP ${ }^{2} \mathrm{E}$ network, and for those who are invested in sustainable prescribing to collaboratively create open educational resources about this (www.prescribingeducation.eu).

Planetary health should be a cross-cutting theme throughout the whole of medical education (ref). Within medical education, prescribing is likely to have the most impact, as human pharmaceuticals not only account for an estimated $25 \%$ of all medical greenhouse gas emissions, but also exert direct ecotoxicological effects via sewage systems[8]. Moreover, prescribers may directly influence their environmental impact through individual treatment decisions. Therefore, while any ready-to-use teaching materials will provide a welcome start, planetary health must be incorporated in the basics of pharmacotherapy education. The six-step model of the WHO guide to good prescribing and the accompanying teacher's guide to good prescribing are currently under revision[9]. Aside from pharmaceutical advances, globalization of information and digitization of both the prescribing process and medical education, the revision will include sustainable medicines use. We expect that specifically step $3(\mathrm{~b})$ of the six-step process - to verify the suitability of a (standard) treatment and adapt it to the individual needs of a patient - will be updated so that prescribers learn to take the environmental impact of their treatment decisions into account. The exact nature of the update will be decided in a consensus meeting with its users, interested readers are welcome to apply via http://www.guidetogoodprescribing.org.

\section{References:}

1. Adeyeye E, New BJM, Chen F, Kulkarni S, Fisk M, Coleman JJ. Sustainable medicines use in clinical practice: A clinical pharmacological view on eco-pharmaco-stewardship. British Journal of Clinical Pharmacology; n/a.

2. General Medical Council. Outcomes for graduates. 2020. . In.

3. Shaw E, Walpole S, McLean M, Alvarez-Nieto C, Barna S, Bazin K, Behrens G, Chase H, Duane B, El Omrani O, Elf M, Faerron Guzmán CA, Falceto de Barros E, Gibbs TJ, Groome J, Hackett F, Harden J, Hothersall EJ, Hourihane M, Huss NM, Ikiugu M, Joury E, Leedham-Green K, MacKenzie-Shalders K, Madden DL, McKimm J, Nayna Schwerdtle P, Parkes MW, Peters S, Redvers N, Sheffield P, Singleton J, Tun S, Woollard R. AMEE Consensus Statement: Planetary health and education for sustainable healthcare. Medical Teacher 2021; 43: 272-86.

4. Bakkum MJ, Tichelaar J, Papaioannidou P, Likic R, Sanz Alvarez EJ, Christiaens T, Costa JN, Mačiulaitis R, Dima L, Coleman J, Richir MC, van Agtmael MA, Pharmacology ftEWGotEAfC, Therapeutics, Pharmacotherapy iaNoTi. Harmonizing and improving European education in prescribing: An overview of digital educational resources used in clinical pharmacology and therapeutics. British Journal of Clinical Pharmacology 2021; 87: 1001-11.

5. Brinkman D, Tichelaar J, Okorie M, Bissell L, Christiaens T, Likic R, Mačìulaitis R, Costa J, Sanz E, Tamba B, Maxwell S, Richir M, van Agtmael M, Pharmacology ftEWGotEAfC, Therapeutics. Pharmacology 
and Therapeutics Education in the European Union Needs Harmonization and Modernization: A Crosssectional Survey Among 185 Medical Schools in 27 Countries. Clinical Pharmacology \& Therapeutics 2017; 102: 815-22.

6. Tun S, Wellbery C, Teherani A. Faculty development and partnership with students to integrate sustainable healthcare into health professions education. Medical Teacher 2020; 42: 1112-18.

7. Bakkum MJ, Richir MC, Papaioannidou P, Likic R, Sanz EJ, Christiaens T, Costa JN, Mačiulaitis R, Dima L, Coleman J, Tichelaar J, van Agtmael MA, Atanasova I, Ganeva M, Gatchev E, Kostadinova II, Matanovic SM, Vitezic D, Wozniak G, Kmonickova E, Urbanek K, Damkier P, Huupponen RK, Auffret M, Bejan-Angoulvant T, Chouchana L, Cracowski J-L, Drici MD, Faillie JL, Geniaux H, Molimard M, Orlikowski D, Palin K, Pers YM, Picard N, Simon N, Toussirot E, Boger RH, Cascorbi I, Mueller SC, Regenthal R, Schwab M, Schwaninger MS, Thuermann PA, Wojnowski L, Kouvelas D, Riba P, Kerins DM, Williams DJ, Cosentino M, De Ponti F, Filippelli A, Leone R, Locatelli V, Jansone B, Gulbinovic R, Mifsud J, Braszko JJ, Kocic I, Breitenfeld L, Castelo-Branco M, Conea S, Magyar I, Bevc S, Krzan M, Bernal ML, Capellà D, Carcas A, De Abajo FJ, Lopez-Rico M, Lucena MI, Pontes C, Sanz EJ, Böttiger Y, Le Grevès M, de WaardSiebinga I, Janssen BJA, Knol W, Pandit R, van Rosse F, Dent G, Ferro A, Hitchings AW, Kapil V, Linton KD, Loke YK, Okorie M, Plumb RD, Pontefract S, Ranmuthu S, Sampson AP, Thanacoody HKR, Whitfield JP, Wilson K, for the Education Working Group of the European Association for Clinical P, Therapeutics, its affiliated Network of Teachers in P. EurOP2E - the European Open Platform for Prescribing Education, a consensus study among clinical pharmacology and therapeutics teachers. European Journal of Clinical Pharmacology 2021; 77: 1209-18.

8. Fent K, Weston AA, Caminada D. Ecotoxicology of human pharmaceuticals. Aquatic Toxicology 2006; 76: $122-59$.

9. Tichelaar J, Richir MC, Garner S, Hogerzeil H, de Vries TPGM. WHO guide to good prescribing is 25 years old: quo vadis? European Journal of Clinical Pharmacology 2020; 76: 507-13. 